\title{
Ultrasound-assisted Crystallisation of Magnesium Hydroxide from Seawater
}

\author{
J. Jakić, M. Labor, D. Jozić, V. Martinac, and I. Horvat \\ Faculty of Chemistry and Technology, Ruđera Boškovića 35, 21000 Split, Croatia
}

This work is licensed under a Creative Commons Attribution 4.0

\begin{abstract}
High purity magnesium hydroxide has been synthesised from seawater with the addition of dolomite lime as reagent. High intensity ultrasound-assisted crystallization of magnesium hydroxide was carried out during precipitation with the intention to obtain fine particles of $\mathrm{Mg}(\mathrm{OH})_{2}$ as well as to prevent their agglomeration. Investigations were conducted on magnesium hydroxide samples in the form of sludge and voluminous powder. The composition, morphology, and properties of the product were determined by chemical, XRD, FTIR, and SEM/EDS analysis. The particle size distribution was detected by the laser light scattering method. The results showed that the mean particle size of magnesium hydroxide sludge was $5.75 \mu \mathrm{m}$, while voluminous powder was $7.58 \mu \mathrm{m}$. The morphology of magnesium hydroxide voluminous powder was in the form of aggregated filamentous (up to $300 \mathrm{~nm}$ in size) or flake structures.
\end{abstract}

\section{Keywords}

Ultrasound, magnesium hydroxide, seawater, precipitation, particle size, microstructure

\section{Introduction}

Magnesium hydroxide is used in a wide range of applications, such as antibacterial agent, neutraliser of acidic water pollutants, liquid wastes and gases, filler in the paper industry, neutralising agent in pharmaceuticals, fertiliser additive, precursor for the production of magnesium oxide, as refractory material and flame retardant. ${ }^{1-4}$

The method of synthesis and the process conditions affect the physicochemical properties of magnesium hydroxide, which are defined by shape, size, and degree of diversity of the particles. ${ }^{4}$ Particles can vary in grain, size, and morphology. Morphology of the synthesised particles can be in different forms: as needles, tubes, fibres, platelets, rods, and flowers. ${ }^{4-8}$

Magnesium hydroxide can be obtained by various methods of synthesis from mineral resources such as magnesite, serpentinite, dolomite, carnallite, mineral salt and seawater. $^{9-11}$ Synthesis methods are sol-gel, chemical precipitation, electrochemical, solvothermal and hydrothermal, methods based on microemulsion, chemical vapour deposition, microwave, sonochemistry, and combustion. ${ }^{4,8,12-17}$

Sonochemistry is the method in which molecules undergo a chemical reaction due to the application of powerful ultrasound radiation $(20 \mathrm{kHz}-10 \mathrm{MHz}){ }^{18}$ The observed chemical transformations generated through ultrasonic irradiation are not due to the interaction between the ultrasound and the substance, but a consequence of the effect of cavitation which the propagating ultrasound waves generate in a medium. Cavitation generates microbubbles with vapour in the liquid, accompanied by an inward collapse when the size of the bubble is no longer tenable

${ }^{*}$ Corresponding author: Jelena Jakić, Ph. D.

E-mail: nina@ktf-split.hr by the propagating ultrasonic waves. This implosion generates very high temperatures (5000-25000 K), pressure $(152 \mathrm{kPa})$, and heating and cooling rate $\left(10^{11} \mathrm{~K} \mathrm{~s}^{-1}\right) \cdot{ }^{18-20} \mathrm{In}$ such extreme conditions, the organisation and crystallisation of the products is hindered, resulting in the formation of smaller crystals. The products obtained with ultrasound can vary in size, shape, structure, and in their solid phase. ${ }^{20}$

In recent years, many kinds of materials have been synthesised in nano size by this method. Some authors ${ }^{15,21-22}$ have successfully synthesised nano magnesium hydroxide from a liquid, while some have modified the surface of micro magnesium hydroxide by ultrasound irradiation. The advantage of this method, compared to other methods, is that it can be easily controlled, is very fast, and needs no surfactant. Products can have good spherical and uniform crystallites with smaller particles. ${ }^{20}$

A detailed review of the literature leads to the conclusion that no one has yet investigated the synthesis of magnesium hydroxide from seawater by ultrasound. Seawater can be economically used as a raw material in the production of magnesium hydroxide if the magnesium mass concentration in it is at least $1.3 \mathrm{~g} \mathrm{dm}^{-3}$. This condition is met in numerous places in seas and oceans. ${ }^{23}$ In this study, magnesium hydroxide was synthesized through precipitation and sonochemistry methods in the presence of dolomite lime as reagent.

The effect of ultrasound irradiation on the size and morphology of particles of magnesium hydroxide from seawater has been investigated. The purpose was to obtain high purity magnesium hydroxide with a smaller particle size, and to prevent agglomeration during synthesis. The properties of the obtained magnesium hydroxide were characterised by the laser light scattering method (LLS), XRD, FTIR and SEM analysis. 


\section{Experimental}

Magnesium hydroxide powders were synthesised by chemical precipitation (Eq. (1)) from seawater (from the location of the Institute of Oceanography, Split) with dolomite lime (from the location of Đipalo-Sinj, Croatia) as the reagent. The chemical analysis of seawater is shown in Table 1. The chemical composition of the dolomite lime was converted from the known chemical composition of dolomite and loss on ignition $\left(950{ }^{\circ} \mathrm{C} / 5 \mathrm{~h}\right.$ ). The chemical composition of dolomite lime is shown in Table 2.

$$
\begin{gathered}
2 \mathrm{CaO} \cdot \mathrm{MgO}(\mathrm{s})+2 \mathrm{Mg}^{2+}(\mathrm{aq})+\mathrm{SO}_{4}{ }^{2-}(\mathrm{aq})+ \\
+2 \mathrm{Cl}^{-}(\mathrm{aq})+ \\
+\mathrm{H}_{2} \mathrm{O}(\mathrm{l}) \rightarrow 4 \mathrm{Mg}(\mathrm{OH})_{2}(\mathrm{~s})+\mathrm{CaSO}_{4}(\mathrm{~s})+ \\
+\mathrm{Ca}^{2+}(\mathrm{aq})+2 \mathrm{Cl}(\mathrm{aq})
\end{gathered}
$$

Table 1 - Chemical composition of seawater, $\mathrm{g} \mathrm{dm}^{-3}$

Tablica 1 - Kemijski sastav morske vode, $\mathrm{g} \mathrm{dm}^{-3}$

\begin{tabular}{c|c|c|c}
\hline $\begin{array}{c}\text { Components, } \mathrm{g} \mathrm{dm}^{-3} \\
\text { Komponente, } \mathrm{g} \mathrm{dm}^{-3}\end{array}$ & $\mathrm{CaO}$ & $\mathrm{MgO}$ & $\mathrm{B}$ \\
\hline Seawater & 0.6945 & 2.4598 & $3.83 \cdot 10^{-3}$ \\
\hline
\end{tabular}

Seawater was pre-treated with sulphuric acid in order to remove bicarbonate $\left(\mathrm{HCO}_{3}{ }^{-}\right)$and carbonate $\left(\mathrm{CO}_{3}{ }^{2-}\right)$ ions, followed by the removal of the liberated carbon dioxide $\left(\mathrm{CO}_{2}\right)$ by aeration in a desorption tower. After pre-treatment of the seawater, a calculated amount of dolomite lime (addition of $80 \%$ of the stoichiometric quantity of dolomite lime) was added to the seawater. The suspension was then ultrasonically irradiated by a high intensity ultrasonic probe immersed directly into the solution. The precipitation reaction took $1 \mathrm{~h}$ under ultrasound waves. The working parameters of the high intensity ultrasound (Hielscher Ultrasound Technology UP400St) were $20 \mathrm{kHz}$, amplitude $50 \%$ with a maximum power output of $100 \mathrm{~W}$. The temperature of suspension throughout the process was kept at $50 \pm 5{ }^{\circ} \mathrm{C}$ by cooling with ice water.

The magnesium hydroxide precipitate was centrifuged (centrifuge TEHTNICA LC-320, $3000 \mathrm{rpm}$ for $5 \mathrm{~min}$ ), and rinsed five times with distilled water $(\mathrm{pH}=5.86)$. The rinsing was carried out five times with approximately $1000 \mathrm{~cm}^{3}$ of the rinsing agent in order to eliminate residual impurities. After the last rinse, the precipitate in the form of sludge was homogenised again by ultrasound for $10 \mathrm{~min}$. This was followed by the freeze-drying method at $-110{ }^{\circ} \mathrm{C}$ with pressures of 5-20 $\mathrm{Pa}$ in a stream of liquid air.

Freeze-drying ${ }^{24}$ is a drying method where the solvent is frozen prior to drying, and is then sublimed, i.e., converted

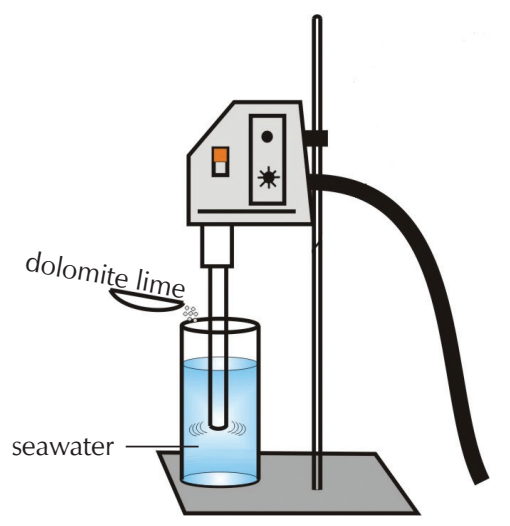

Fig. 1 - Schematic illustration of $\mathrm{Mg}(\mathrm{OH})_{2}$ synthesis by ultrasound

Slika 1 - Shematski prikaz sinteze $\mathrm{Mg}(\mathrm{OH})_{2}$ ultrazvukom

to the gas phase directly from the solid phase, below the melting point of the solvent. The pressure can be lowered by a device with a special cooler and a two-stage vacuum pump. The drying process was carried out for three days. The magnesium hydroxide samples were chemically analysed to determine concentrations of $\mathrm{CaO}, \mathrm{MgO}, \mathrm{Al}_{2} \mathrm{O}_{3}$, $\mathrm{Fe}_{2} \mathrm{O}_{3}, \mathrm{~B}_{2} \mathrm{O}_{3}$, and $\mathrm{SiO}_{2}$ using the complexometric, potentiometric, and gravimetric methods, respectively.

The XRD analysis of $\mathrm{Mg}(\mathrm{OH})_{2}$ was performed with a PANalytical Empyrean X-ray diffraction system with the following operating conditions: $\mathrm{Cu}-\mathrm{K} \alpha, 40 \mathrm{kV}$ voltage and $40 \mathrm{~mA}$ current, $0.0263^{\circ}$ step size, counting time/step of $97 \mathrm{~s}$, and a scanning angle $2 \theta$ from 13 to $120^{\circ}$. The XRD pattern was collected with constant irradiated surface (observed length $3 \mathrm{~mm}$ ) using automatic divergent slit (ADS). In the procedure of data treatment, the collected pattern was corrected for convert divergence slit and systematic errors (external Si standard). The qualitative interpretation of the XRD pattern was made by comparison with standard patterns contained in the database PDF2 (ICDD, PDF2 Released 2020) using HighScore Plus. Quantitative analysis was made using Direct Derivative (DD) quantification method. ${ }^{25}$ The FT-IR spectroscopic measurements were recorded on a Spectrum One instrument (PerkinElmer, SAD) at room temperature in the range from 400 to $4000 \mathrm{~cm}^{-1}$. A sample of magnesium hydroxide after the drying process, in the form of voluminous powder $\left(\mathrm{vMg}(\mathrm{OH})_{2}\right)$ was prepared by the potassium bromide $(\mathrm{KBr})$ pellet method. The average particle sizes of magnesium hydroxide samples before and after the drying process were detected by a laser particle size analyser (Mastersizer 2000, PerkinElmer). The range of measurements was from $20 \mathrm{~nm}$ to $2 \mathrm{~mm}$. The measurements were made with the refractive index

Table 2 - Chemical composition of dolomite lime, mass. \%

Tablica 2 - Kemijski sastav dolomitnog vapna, mas \%

\begin{tabular}{c|c|c|c|c|c}
\hline $\begin{array}{c}\text { Components, mass. \% } \\
\text { Komponente, mas \% }\end{array}$ & $\mathrm{CaO}$ & $\mathrm{MgO}$ & $\mathrm{Al}_{2} \mathrm{O}_{3}$ & $\mathrm{Fe}_{2} \mathrm{O}_{3}$ & $\mathrm{SiO}_{2}$ \\
\hline Dolomite lime & 59.03 & 40.69 & 0.0925 & 0.0705 & 0.1083 \\
\hline
\end{tabular}


Table 3 - Chemical composition of $\mathrm{Mg}(\mathrm{OH})_{2}$ sample before calcination (a) and after calcination (b), mass. \%

Tablica 3 - Kemijski sastav uzorka $\mathrm{Mg}(\mathrm{OH})_{2}$ prije (a)i nakon kalciniranja (b), mas \%

\begin{tabular}{c|c|c|c|c|c|c|c}
\hline $\begin{array}{c}\text { Components, mass. \% } \\
\text { Komponente, mas \% }\end{array}$ & $\mathrm{CaO}$ & $\mathrm{MgO}$ & $\mathrm{Al}_{2} \mathrm{O}_{3}$ & $\mathrm{Fe}_{2} \mathrm{O}_{3}$ & $\mathrm{~B}_{2} \mathrm{O}_{3}$ & $\mathrm{SiO}_{2}$ & L.O.I. \\
\hline Sample (a) & 1.120 & 65.450 & 0.038 & 0.035 & 0.192 & 0.121 & 32.150 \\
\hline Sample (b) & 1.651 & 96.463 & 0.056 & 0.052 & 0.283 & 0.178 & - \\
\hline
\end{tabular}

*Chemical composition of Sample (a) is expressed through the oxide form for the sake of comparison with Sample (b) after calcination.

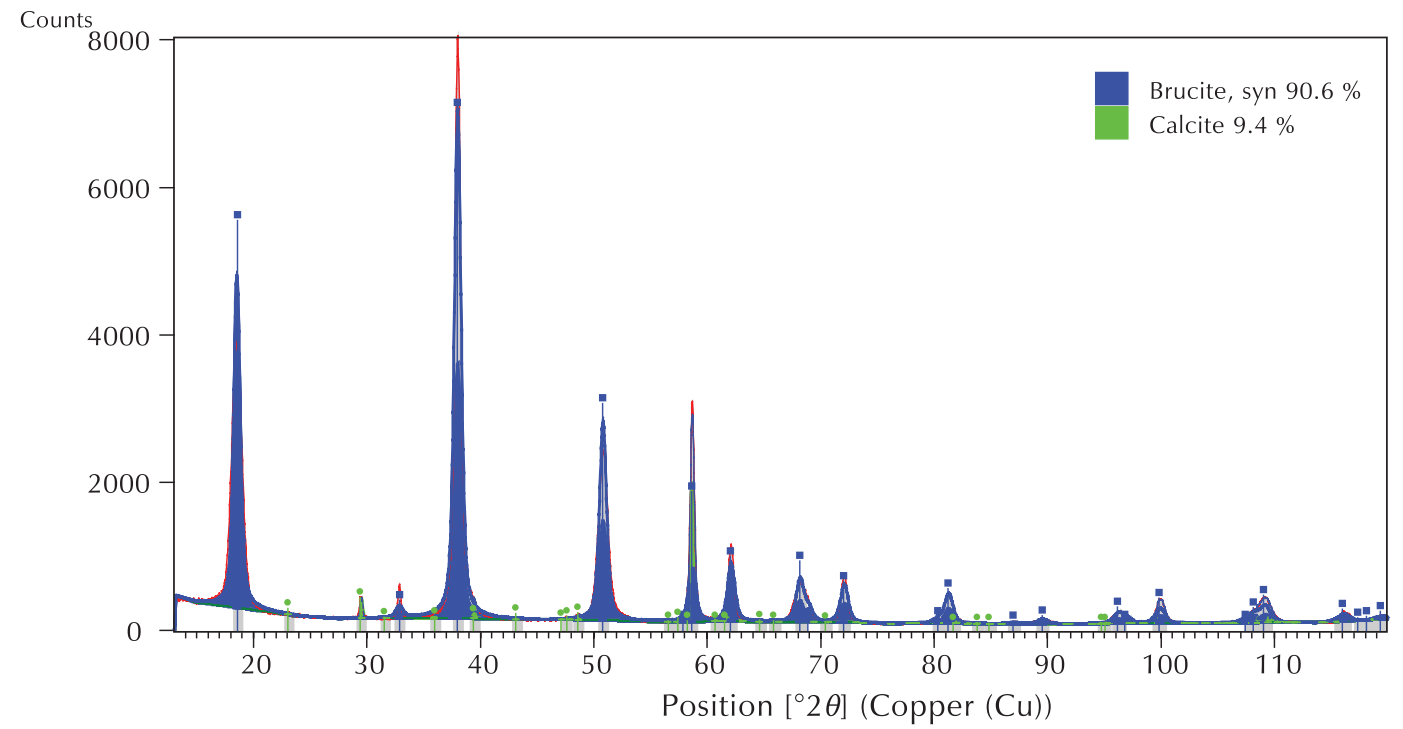

Fig. 2 - X-ray diffractogram of $\mathrm{Mg}(\mathrm{OH})_{2}$ sample after the drying process

Slika 2 - Rendgenski difraktogram uzorka $\mathrm{Mg}(\mathrm{OH})_{2}$ nakon procesa sušenja

of 1.580. The morphology and structure of magnesium hydroxide samples were analysed using scanning electron microscopy (SEM/EDS, JEOL JSM-7000).

\section{Results and discussion}

The results of the chemical analysis (shown in Table 3) indicate a high quality magnesium hydroxide precipitate obtained by the process of precipitation from seawater with $80 \%$ of dolomite lime. Previous studies ${ }^{26,27}$ indicate a much faster precipitation rate and a cleaner precipitate when the quantity of the precipitation agent used is smaller than the stoichiometric one. Also, the addition of a smaller amount of dolomite lime in the process of precipitation of magnesium hydroxide from seawater decreases the coagulation stability of the colloidal system by decreasing the electrokinetic potential, thus achieving an isoelectric point faster $(\zeta=0)$, the results of which cause an increase in the rate of sedimentation and an increase in the capacity of the thickener. The chemical composition indicates a high percentage of $\mathrm{MgO}$ (96.463\%) in the sample, and as such it has a wide range of applications.

The XRD powder pattern of the synthesized $\mathrm{Mg}(\mathrm{OH})_{2}$ sample is shown in Fig. 2. The results of the analysis suggest- ed that the prepared sample consisted of two structurally ordered phases $\mathrm{Mg}(\mathrm{OH})_{2}$ (brucite) and $\mathrm{CaCO}_{3}$ (calcite) in the amount of 90.6 and 9.4 mass. \%, respectively. The synthesized $\mathrm{Mg}(\mathrm{OH})_{2}$ crystallised in the hexagonal crystal system in the space group P-3m1. Parameters of unit cell of the $\mathrm{Mg}(\mathrm{OH})_{2}$ model used (brucite, PDF 01-084-2163) were $\mathrm{a}=\mathrm{b}=3.148 \AA$ and $\mathrm{c}=4.779 \AA$. After refinement by application of direct derivative method the parameters of unit cell were $\mathrm{a}=\mathrm{b}=3.144 \AA$ and $\mathrm{c}=4.777 \AA$, which were less than in the used model (GOF $=3.38$, and Rwp = 11.79). Crystallite size of $\mathrm{Mg}(\mathrm{OH})_{2}$ was $129.7 \AA$.

Fig. 3 shows the results of the FT-IR analysis of magnesium hydroxide sample obtained by non-stoichiometric (80\%) precipitation in the form of voluminous powder. Absorption bands located at the $3699.78 \mathrm{~cm}^{-1}, 647.38 \mathrm{~cm}^{-1}$, and $583.23 \mathrm{~cm}^{-1}$ are attributed to the brucite. ${ }^{28-29}$ The main and very sharp absorption band at the $3699.78 \mathrm{~cm}^{-1}$ is attributed to stretching vibration of the $\mathrm{O}-\mathrm{H}$ bond in the brucite crystal structure. $\mathrm{Mg}-\mathrm{O}-\mathrm{H}$ bending mode in brucite occurs at low frequencies, suggested by the absorption bands at $583.23 \mathrm{~cm}^{-1}$ and $647.38 \mathrm{~cm}^{-1}$. Very broad absorption band located in the range between 3600 and $3000 \mathrm{~cm}^{-1}$ and cantered at $3421 \mathrm{~cm}^{-1}$ are attributed to the stretching vibration of the $\mathrm{O}-\mathrm{H}$ bond from the molecule of water. Absorption band at $1637.8 \mathrm{~cm}^{-1}$ is assigned to the bending vibration of the $\mathrm{H}-\mathrm{OH}$ bond, which arises also from the 


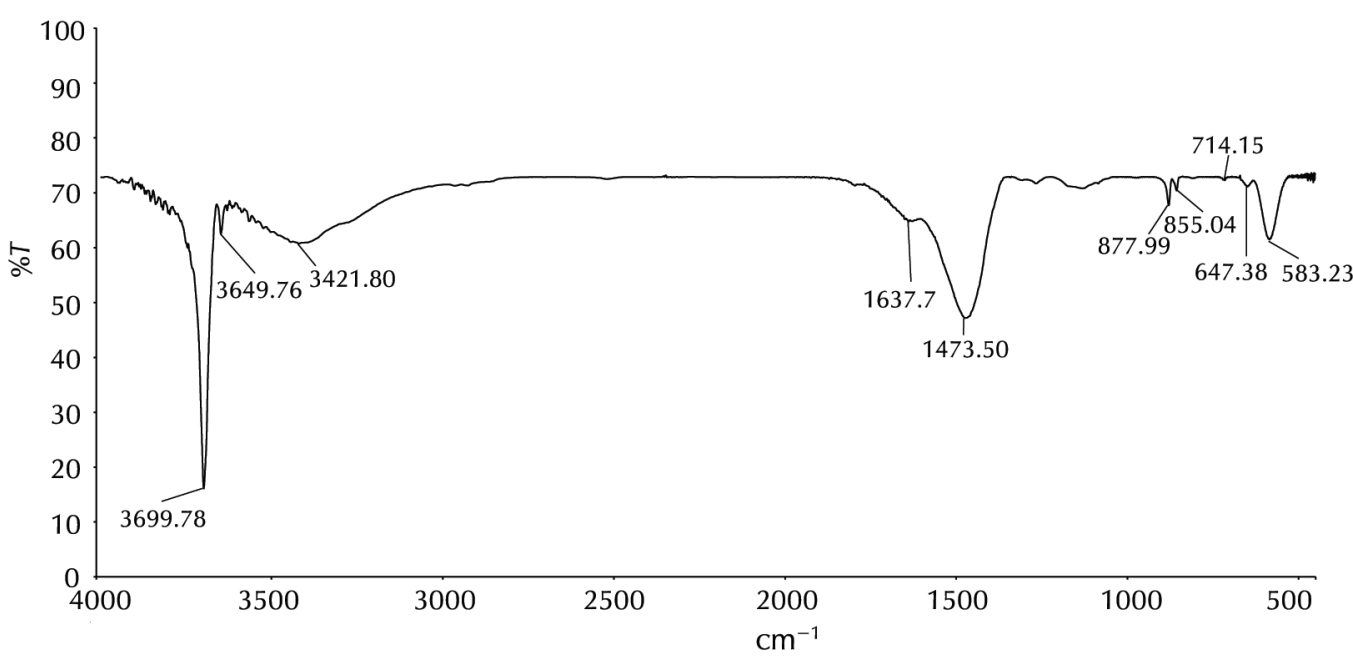

Fig. 3 - FTIR spectra of $\mathrm{Mg}(\mathrm{OH})_{2}$ samples in the form of voluminous powder Slika 3 - FTIR spektri uzorka $\mathrm{Mg}(\mathrm{OH})_{2}$ u obliku voluminoznog praha

molecule of adsorbed water on the surface of the sample. ${ }^{28}$ The weak absorption band located at $3649.76 \mathrm{~cm}^{-1}$ is attributed to the $\mathrm{O}-\mathrm{H}$ stretching vibration in $\mathrm{Ca}(\mathrm{OH})_{2}{ }^{30}$ The broad band at $1473.50 \mathrm{~cm}^{-1}$ and a weak band at $877.90 \mathrm{~cm}^{-1}$ indicate the rapid formation of the carbonate from the hydroxide. Observed absorption bands attributed to $\mathrm{CaCO}_{3}$ are in-plane bending $\left(v_{4}\right)$ at $714.15 \mathrm{~cm}^{-1}$, outof-plane bending mode $\left(v_{2}\right)$ at $877.9 \mathrm{~cm}^{-1}$ and asymmetric stretching $\left(v_{3}\right)$ mode at $1473.50 \mathrm{~cm}^{-1} \cdot{ }^{31}$

The results of the FTIR analysis confirmed the content of brucite and calcite phases in the samples of magnesium hydroxide obtained from seawater.

In order to examine the effect of high-intensity ultrasound on the particle size of the precipitate obtained, analysis of particle size distribution was carried out on magnesium hydroxide samples in the form of sludge before the drying process (Fig. 4). The samples were analysed without the application of ultrasound and with its application for $100 \mathrm{~s}$ immediately before measurement.

The results indicated that the application of ultrasound for $100 \mathrm{~s}$ affected the breaking of formed agglomerates. The optimal time of ultrasound application was $100 \mathrm{~s}$, because after further application, no changes were observed in the samples when particle size distribution was measured. The results indicated that the particle size distribution had shifted towards lower values, i.e. in the range from 0.1 to $34.6 \mu \mathrm{m}$. The mean particle size was $5.75 \mu \mathrm{m}$.

Fig. 5 shows the analysis of particle size distribution performed on magnesium hydroxide samples in the form of voluminous powder after the drying process. The samples were dispersed in water with the application of ultrasound for $20 \mathrm{~s}$ or $100 \mathrm{~s}$ immediately before measurement. The optimal time for ultrasound application was $20 \mathrm{~s}$, because after further application, a new agglomeration of particles was observed. The results indicated that the particle size distribution ranged from 0.1 to $39.8 \mu \mathrm{m}$. The mean particle size was $7.58 \mu \mathrm{m}$.

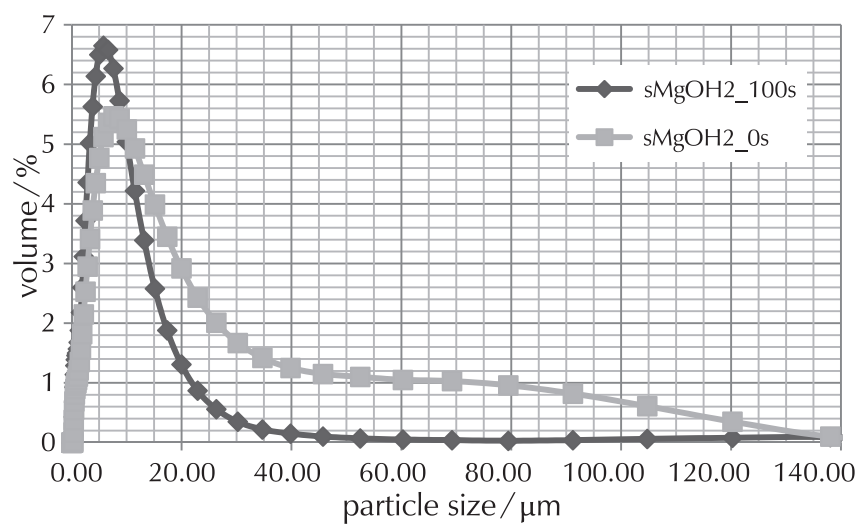

Fig. 4 - Particle size distribution for $\mathrm{sMg}(\mathrm{OH})_{2}$ sample

Slika 4 - Raspodjela veličine čestica za uzorak $\mathrm{Mg}(\mathrm{OH})_{2}$ u obliku mulja

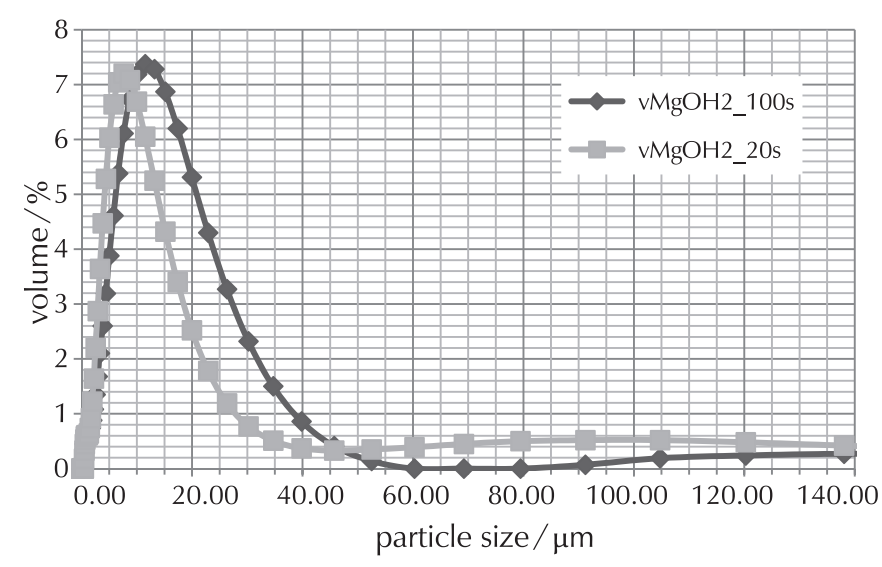

Fig. 5 - Particle size distribution for $v \mathrm{Mg}(\mathrm{OH})_{2}$ sample

Slika 5 - Raspodjela veličine čestica za uzorak $\mathrm{Mg}(\mathrm{OH})_{2}$ u obliku voluminoznog praha 
The application of high-intensity ultrasound affects the particle size by breaking the formed magnesium hydroxide agglomerates both in the precipitation process and after drying. The comparison of particle size distribution in magnesium hydroxide samples in the form of sludge and in the form of voluminous powder showed a deviation (Fig. 6). It was assumed that the formation of adhesions had occurred which could not be broken even after treating the samples with ultrasound. The purpose was to maintain the particle size of the precipitated magnesium hydroxide (in the form of sludge) even after drying, meaning that the freeze-drying method was not fully effective.

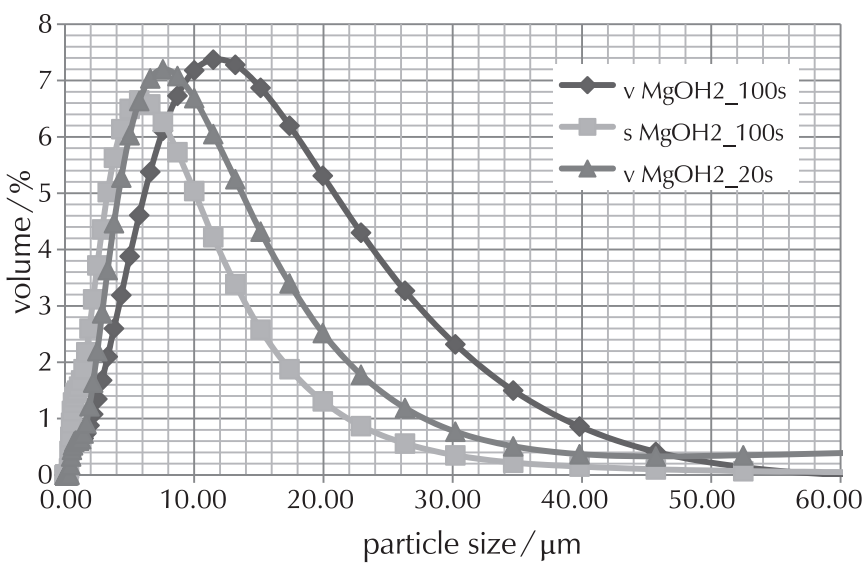

Fig. 6 - Particle size distribution for $s \mathrm{Mg}(\mathrm{OH})_{2}$ and $v \mathrm{Mg}(\mathrm{OH})_{2}$ samples

Slika 6 - Raspodjela veličina čestica za uzorke $\mathrm{Mg}(\mathrm{OH})_{2}$ u obliku mulja i volumonoznog praha

SEM images (Fig. 7) were used to study the morphology of the voluminous powder of magnesium hydroxide. Various magnifications of the images of magnesium hydroxide samples obtained by the freeze-drying method show flaky and filamentous structures of irregular shape agglomerated into much larger formations. Filamentous structures were up to $300 \mathrm{~nm}$ long, and flakes were much larger. The EDS analysis indicated a high percentage of $\mathrm{Mg}^{2+}$ in the sample.

\section{Conclusion}

By the process of precipitation from seawater with dolomite lime, high purity magnesium hydroxide, i.e., with a high content of $\mathrm{MgO}(96.463 \%)$ in the sample, has been successfully obtained, and as such can be used as a starting material in many industries. The prepared sample consisted of two structurally ordered phases $\mathrm{Mg}(\mathrm{OH})_{2}$ (brucite) and $\mathrm{CaCO}_{3}$ (calcite) in the amount of 90.6 and 9.4 mass. \%, respectively. The application of high-intensity ultrasound had no effect on the chemical composition of the obtained magnesium hydroxide precipitate, which was evident from the chemical, XRD and FTIR analysis. The application of high-intensity ultrasound significantly contributed to the reduction in particle size of the precipitated magnesium hydroxide. The mean particle size of the mag-

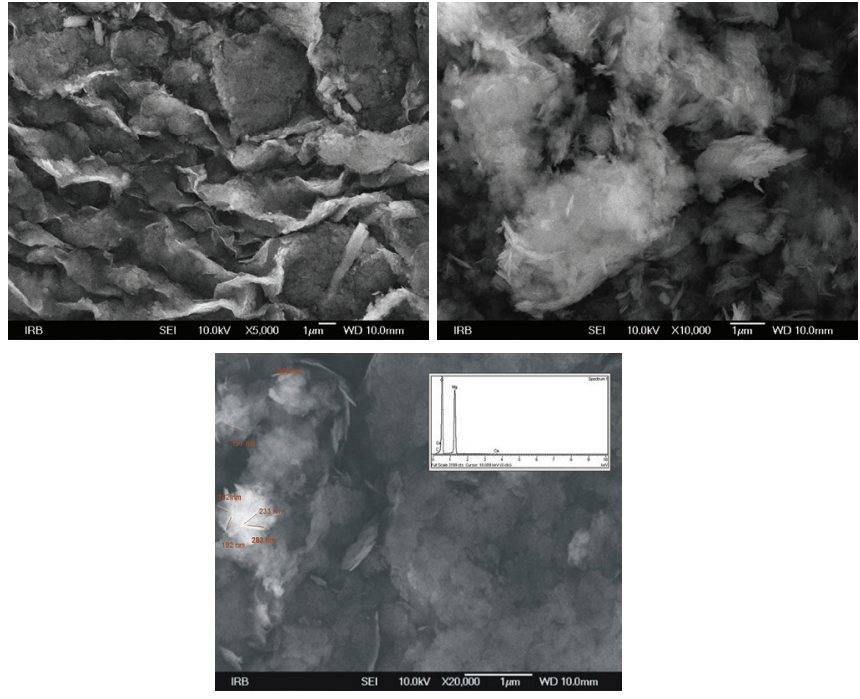

Fig. 7 - SEM images of the $v \mathrm{Mg}(\mathrm{OH})_{2}$ sample with EDS analysis, at $5.000 \times(a), 10.000 \times(b)$, and $20.000 \times$ (c) magnification

Slika 7 - SEM snimke uzorka $v \mathrm{Mg}(\mathrm{OH})_{2}$ s EDS analizom pri povećanju od $5.000 \times(a), 10.000 \times$ (b) i $20.000 \times$ (c)

nesium hydroxide sludge was $5.75 \mu \mathrm{m}$, and that of voluminous powder was $7.58 \mu \mathrm{m}$. The freeze-drying method failed to maintain the same particle size of magnesium hydroxide as in the sludge samples. Deviations in particle size between sludge samples and voluminous powder samples of magnesium hydroxide after the ultrasonic treatment indicated the formation of adhesions. The morphology of voluminous powder of magnesium hydroxide showed flaky and filamentous structures of irregular shape agglomerated into much larger formations ( $\mu \mathrm{m}$ size range). Filamentous structures were up to $300 \mathrm{~nm}$ long, while the flakes were much larger.

\section{References \\ Literatura}

1. H. Li, S. Liu, J. Zhao, N. Feng, Removal of reactive dyes from wastewater assisted with kaolin clay by magnesium hydroxide coagulation process, Colloids Surf. A Physicochem. Eng. Asp. 494 (2016) 222-227, doi: https://doi.org/10.1016/j. colsurfa.2016.01.048.

2. H. Cao, H. Zheng, J. Yin, Y Lu, S. Wu, X. Wu, B. Li, Mg(OH) Complex nanostructures with superhydrophobicity and flame retardant effects, J. Phys. Chem. C. 114 (2010) 17362-17368, doi: https://doi.org/10.1021/jp107216z.

3. L. Zong, L. Li, J. Zhang, X. Yang, G. Lu, Z. Tang, Synthesis of High Dispersion and Uniform Nano-sized Flame Retardant-Used Hexagonal $\mathrm{Mg}(\mathrm{OH})_{2}$, J. Clust. Sci. 27 (2016) 1831-1841, doi: 10.1007/ s10876-016-1045-4

4. A. A. Pilarska, Ł. Klapiszewski, T. Jesionowski, Recent developments in the synthesis, modification and application of $\mathrm{Mg}(\mathrm{OH})_{2}$ and $\mathrm{MgO}$ : A review, Powder Technol. 319 (2017) 373-407, doi: https://doi.org/10.1016/j.powtec.2017.07.009.

5. J. P. Lv, L. Z. Qiu, B. J. Qu, Controlled growth of three morphological structures of magnesium hydroxide nanoparticles by 
wet precipitation method, J. Cryst. Growth 267 (2004) 676684, doi: https://doi.org/10.1016/j.jcrysgro.2004.04.034.

6. P. Wang, C. H. Li, H. Y. Gong, H. Wang, J. Liu, Morphology control and growth mechanism of magnesium hydroxide nanoparticles via a simple wet precipitation method, Ceram. Int. 37 (2011) 3365-3370, doi: https://doi.org/10.1016/j. ceramint.2011.05.138.

7. Y. Ding, G. T. Zhang, H. Wu, B. Hai, L. B. Wang, Y. T. Qian, Nanoscale magnesium hydroxide and magnesium oxide powders: Control over size, shape, and structure via hydrothermal synthesis, Chem. Mater. 13 (2001) 435-440, doi: https://doi.org/10.1021/cm000607e.

8. H. Chen, C. Xu, Y. Liu, G. Zhao, Formation of flower-like magnesium hydroxide microstructure via a solvothermal process, electron, Mater. Lett. 8 (2012) 529-533, doi: https://doi. org/10.1007/s13391-012-2062-6.

9. Q. Hai-Yan, D. Min, Z. Shao-Ming, X. Ling-Ling, Synthesis of superfine $\mathrm{Mg}(\mathrm{OH})_{2}$ particles by magnesite, Mat. Sci. Eng. A (2007) 600-603, doi: https://doi.org/10.1016/j. msea.2006.09.079.

10. V. Sirota, V. Selemenev, M. Kovaleva, I. Pavlenko, K. Mamunin, V. Dokalov, M. Yapryntsev, Preparation of crystalline $\mathrm{Mg}(\mathrm{OH})_{2}$ nanopowder from serpentinite mineral, Int. J. Min. Sci. Technol. 28 (2018) 499-503, doi: https://doi. org/10.1016/j.ijmst.2017.12.018.

11. M. A. Shand, The Chemistry and Technology of Magnesia, Wiley, New York, 2006, pp. 39-60, doi: https://doi. org/10.1002/0471980579.

12. D. K. Chanda, P. S. Das, A. Samanta, A. Dey, A. K. Mandal, K. D. Gupta, T. Maity, A. K. Mukhopadhyay, Intertwined nanopetal assembly of $\mathrm{Mg}(\mathrm{OH})_{2}$ powder, Ceram. Int. 40 (2014) 11411-11417, doi: https://doi.org/10.1016/j.ceramint.2014.03.070

13. Y. Chen, T. Zhou, H. Fang, S. Li, Y. Yao, Y. He, A novel preparation of nano-sized hexagonal $\mathrm{Mg}(\mathrm{OH})_{2}$, Procedia Eng. 102 (2015) 388-394, doi: https://doi.org/10.1016/j.proeng.2015.01.169.

14. H. Dhaouadi, H. Chaabane, F. Touati, $\mathrm{Mg}(\mathrm{OH})_{2}$ nanorods synthesized by a facile hydrothermal method in the presence of CTAB, Nano-Micro Lett. 3 (2011) 153-159, doi: https://doi.org/10.1007/BF03353666.

15. M. A. Alavi, A. Morsali, Syntheses and characterization of $\mathrm{Mg}(\mathrm{OH})_{2}$ and $\mathrm{MgO}$ nanostructures by ultrasound method, Ultrason. Sonochem. 17 (2010) 441-446, doi: https://doi. org/10.1016/j.ultsonch.2009.08.013.

16. R. Al-Gaashani, S. Radiman, Y. Al-Douri, N. Tabet, A. R. Daud, Investigation of the optical properties of $\mathrm{Mg}(\mathrm{OH})_{2}$ and $\mathrm{MgO}$ nanostructures obtained by microwave-assisted methods, J. Alloy. Comp. 521 (2012) 71-76, doi: https://doi. org/10.1016/j.jallcom.2012.01.045.

17. W. Jiang, X. Hua, Q. Han, X. Yang, L. Lu, X. Wang, Preparation of lamellar magnesium hydroxide nanoparticles via precipitation method, Powder Technol. 191 (2009) 227-230, doi: 10.1016/j.powtec.2008.10.023.

18. K. S. Suslick, Sonochemistry, Science 247 (1990) 14391445, doi: https://doi.org/10.1126/science.247.4949.1439.

19. T. J. Mason, J. P. Lorimer, Applied sonochemistry: The Uses of Power Ultrasound in Chemistry and Processing, WileyVCH Verlag, Weinheim, 2002, doi: https://doi.org/10.1002/ jctb.957.

20. A. Gedanken, Using sonochemistry for the fabrication of nanomaterials, Ultrason. Sonochem. 11 (2004) 47-55, doi: https://doi.org/10.1016/j.ultsonch.2004.01.037.

21. G. Song, S. Ma, G. Tang, X. Wang, Ultrasonic-assisted synthesis of hydrophobic magnesium hydroxide nanoparticles, Colloid. Surf. A: Physicochem. Eng. Aspect. 364 (2010) 99104, doi: https://doi.org/10.1016/j.colsurfa.2010.04.043.

22. F. Zhang, H. Zhang, Z. Su, Surface treatment of magnesium hydroxide to improve its dispersion in organic phase by the ultrasonic technique, Appl. Surf. Sci. 253 (2007) 73937397, doi: https://doi.org/10.1016/j.apsusc.2007.03.022.

23. E. Brown et al., Seawater: Its compositions, properties and behaviour, Butterworth Heinemann in association with The Open University, Walton Hall, Milton Keynes, 2 2d Ed., 1997.

24. T. G. Tamboli, M. G. Bhong, Review on Different Drying Methods: Applications \& Advancements, IJTARME 7 (2018) 2319-3182, doi:

25. H. Toraya, Direct derivation (DD) of weight fractions of individual crystalline phases from observed intensities and chemical composition data: incorporation of the DD method into the whole-powder-pattern fitting procedure, J. Appl. Cryst. 51 (2018) 446-455, doi: https://doi.org/10.1107/ S1600576718001474.

26. V. Martinac, M. Labor, N. Petric, N. Arbunić, Sedimentation of Magnesium Hydroxide in Seawater and its Effects on Plant Capacity, Indian J. Mar. Sci. 26 (1997) 335-340.

27. V. Martinac, M. Labor, N. Petric, Examination of Precipitation of Magnesium Hydroxide in Seawater, Chem. Biochem. Eng. Q. 12 (1998) 101-107.

28. H. A. Prescott, Z. J. Li, E. Kemnitz, J. Deutsch, H. Lieske, New magnesium oxide fluorides with hydroxy groups as catalysts for Michael additions, J. Mater. Chem. 15 (2005) 46164628, doi: https://doi.org/10.1039/B510108E.

29. P. A. Schroeder, Infrared Spectroscopy in clay science, Teach. Clay Sci. 11 (2002) 181-206, doi: https://doi.org/10.1346/ CMS-WLS-11.11.

30. M. A. Legodi, D. De Waal, J. H. Potgieter, S. S. Potgieter, Rapid determination of $\mathrm{CaCO}_{3}$ in mixtures utilising FT-IR spectroscopy, Mineral. Eng. 14 (2001) 1107-1111, doi: https:// doi.org/10.1016/S0892-6875(01)00116-9.

31. S. Gopi, V. K. Subramanian, K. Palanisamy, Aragonite-calcite-vaterite: A temperature influenced sequential polymorphic transformation of $\mathrm{CaCO}_{3}$ in the presence of DTPA, Material. Res. Bullet. 48 (2013) 1906-1912, doi: https://doi. org/10.1016/j.materresbull.2013.01.048. 


\section{SAŽETAK}

\section{Ultrazvučno potpomognuta kristalizacija magnezijeva hidroksida iz morske vode \\ Jelena Jakić, Miroslav Labor, Dražan Jozić, Vanja Martinac i Ivona Horvat}

Magnezijev hidroksid visoke čistoće sintetiziran je iz morske vode uz dodatak dolomitnog vapna. Ultrazvukom visokog intenziteta potpomognuta kristalizacija magnezijeva hidroksida tijekom precipitacije odvijala se u svrhu dobivanja što finijih čestica $\mathrm{Mg}(\mathrm{OH})_{2}$ i sprječavanja njihove aglomeracije. Ispitivanja su provedena na uzorcima magnezijeva hidroksida u obliku mulja i voluminoznog praha. Sastav, morfologija i svojstva dobivenog produkta analizirani su kemijskom, XRD, FTIR i SEM/EDS analizom. Raspodjela veličine čestica određena je metodom raspršenja laserskog svjetla. Rezultati ukazuju na to da je srednja veličina čestica magnezijeva hidroksida u obliku mulja $5,75 \mu \mathrm{m}$, dok je u voluminoznom prahu 7,58 $\mu \mathrm{m}$. Morfologija voluminoznog praha magnezijeva hidroksida je u obliku aglomeriranih nitastih (duljine do $300 \mathrm{~nm}$ ) i ljuspičastih struktura.

\section{Ključne riječi}

Ultrazvuk, magnezijev hidroksid, morska voda, precipitacija, veličina čestica, mikrostruktura

Kemijsko-tehnološki fakultet

Ruđera Boškovića 35

21000 Split, Hrvatska
Izvorni znanstveni rad Prispjelo 25. svibnja 2020. Prihvaćeno 8. kolovoza 2020. 